\title{
SEARCH, CHOICE AND PERSISTENCE FOR HIGHER EDUCATION: A CASE STUDY IN TURKEY
}

\author{
Erdal Tatar \\ Münir Oktay
}

\begin{abstract}
The purpose of this study was to investigate students' behaviors in search and choice during university placement, and also to examine how students' choice process affects on their persistence decisions. Participants in the study were 51 second year students studying in the Department of Chemistry Education of Kazim Karabekir Education Faculty, in Ataturk University, in Turkey. The survey instrument used in this study employed a scale to identify sources of information benefited, types of information obtained and factors which students took into consideration in choice process. In addition to this, a semi-structured interview was used to take profound information about this process. The study indicates that most of the students choose their program by an inadequate search process. Findings also indicate that the students show negative behaviors in their decision making process. Finally, a persistence phase is suggested for college or university choice process.
\end{abstract}

KEYWORDS. Higher Education, Chemistry Teacher, Choice Process, Persistence Decision, Turkey, University.

\section{INTRODUCTION}

As in some other countries, such as China, Japan, Greece and Iran, entrance to higher education in Turkey is determined through a nationwide examination. Universities in Turkey recruit students according to their scores of an examination that is named Student Selection Examination (SSE). The SSE is held in all city centers of the country at the same time after students complete secondary education. This exam gives students the right to be placed in colleges, faculties and different departments of the Open University.

In recent years, there has been an increasing demand for higher education in Turkey. Student Selection and Placement Center (SSPC) reported that almost one-and-a-half-million students have taken SSE in every year of the last decade. However, some of these students had already been placed into a higher education institution. In 2004, 14,2\% of the students taken SSE were already enrolled in a higher education program (SSPC 2004). Also, 11 (22\%) of the second year students studying in the Department of Chemistry Education of Kazim Karabekir Education 
Faculty, in Ataturk University, in Turkey took SSE again in this year. This may be due to a change in students' decision that they might want to change the university, the program or both. In addition, $4(8 \%)$ of the students who are in this class passed to another university by lateral transfer when they are at the end of the first year in 2003.

There are three different ways to change the institution for undergraduates in the Turkish higher education system. First, students may seek reentry to a higher education program by taking SSE again. This generally occurs when students are at the end of the second year, because, the SSE scores of the students are reduced if he or she takes SSE at the end of the first year. However this is not done at the end of the second year and the following years. Second, students may use the right of lateral transfer providing that student will pass to another university but to the same program if she/he gets adequate grades from the courses taken. Students who make lateral transfers may continue to study at the level they left. Third, students may use the right of vertical transfer which means: the student can enter any university and the same or a similar program by taking SSE again. The students who make vertical transfer may continue to study at the level they left.

Tatar (2003) states that choosing a higher education program is almost the same as choosing a job in Turkey. The most important factor which affects program selection is the job opportunities in the future. On the other hand, in 2003, 27,9\% of the population unemployed consisted of graduates from secondary and tertiary level in Turkey (TIS 2004).

\section{THEORETICAL FRAMEWORK}

Making college choice decision is a critical stage for all high school graduates who plan to attain higher education in future. However, the college students may make decisions which will affect persistence which is a critical stage in their education. They may make decisions to leave, reenroll or transfer to another higher education institution or continue their studies in their current college.

How does student's choice affect their persistence? Which college choice behaviors lead to leave from an institution of higher education? To answer these questions needs to examine both college choice and persistence decisions.

The literature on student college choice suggests a three-stage process for decisions to go to college (Jackson 1982; Litten 1982; Chapman 1984; Hossler and Gallagher 1987; Hossler et al. 1989). Hossler and Gallagher (1987) proposed the stages of college choice process as follows: 
- The first stage is the predisposition phase in which students determine whether they would like to continue their education beyond the secondary level or not. This phase is affected by student ability, achievement, socioeconomic status, parent, peer, educational activities and school characteristics (Tillery 1973; Litten 1982; Stage and Hossler 1989; Nora and Cabrera 1992; Somers et al. 1999).

- The second stage is the search phase during which they gather information about institutions of higher education and formulate a choice set that is the group of institutions to which students will actually apply. The search phase is affected by students' preliminary college values, their search activities and college or university search activities for students (Hossler and Gallagher 1987; Chapman 1981).

- The third stage is that of choice, that is, deciding which college or university a student will actually attend. Educational and occupational aspirations, costs and financial aids and college or university courtship activities influenced the choice phase (Hossler and Gallagher 1987; John 1990; Nora and Cabrera 1992).

On the other hand, student persistence is defined as behavior of whether an enrolled student chooses to reenroll or continue his or her studies during the next semester or year (Astin 1975; Pascarella and Terenzini 1980; Tinto 1987).

In the literature, there are many studies examining college choice behaviors and persistence. Also, it is known that students' background characteristics, personal characteristics, costs and financial aids and academic and social variables influence both choice and persistence (Bean 1990; Hossler et al. 1989; Paulsen 1990; Cabrera et al. 1992). But it wasn't examined adequately how college choice process affects persistence.

The purpose of this study is to investigate students' behaviors in search and choice phases during the university choice process, and also to examine how the students' choice process affects their persistence.

\section{METHOD}

A survey instrument based on studies concerned with the process of placement into higher education programs was developed (Brenan 2001; Frisbee et al. 2000; Osoro et al. 2000; Price et al. 2001; Belcher et al. 2003). The instrument consisted of four sections. The first section concerned demographic information about the students. In the second section, there were questions concerned with the sources of information that student used in decision making for the program and the university. The third section aimed to determine types of information that students collected. Finally, the fourth section aimed to determine factors which students took into 
consideration in the university entry process. The instrument was piloted with a group of 115 freshmen who studying in the Department of Mathematics and Computer Education. These students and also three faculty members in the Department of Chemistry Education were asked to establish content and face validity for the instrument. They were asked to make changes or offer suggestions for the addition or deletion of items, and to evaluate the overall format and appearance of the instrument.

As a result, the items concerned with faculty magazines, student clubs, and recruitment office of faculty were deleted from the instrument because these did not exist at the time students made their decisions. However, the item relating to brochures and handbooks was added to the instrument. The revised instrument finally included 10 items of types of information actually used (see Table 1), 11 items of sources of information students used (see Table 2) and 17 items of factors that students may take into consideration during choice process (see Table 3). Finally, this survey was administered to 51 second year students studying in the Department of Chemistry Education.

In addition to the survey, 11 students who had retaken SSE were interviewed. Semistructured interviews were held. The interviews were recorded on audiotapes after taking the interviewees' consent.

In analyzing the survey results, descriptive analysis techniques were used and results were tabulated in terms of frequencies and percentages. To identify a relationship between types of information source used and amount of information obtained, the Chi-Square analysis technique was used. Interview data were analyzed by using content analysis technique. Initially, all the responses were read, patterns were identified and first categorization was done. Then the responses were tallied and finally similar categories were combined and final categorization was made. Results are presented under three main headings: search, choice and persistence.

\section{RESULTS}

\section{Survey Analysis}

The results of the survey data analyses are tabulated and given in Table 1,2 and 3. As shown in Table 1, information of admission criteria was the most used type of information. It has been gathered by all the students. This finding shows similarity with the previous studies. Hughes (1994) states that students who are not as capable may seek an institution where access is more readily available, however they may maximize their choices within their self perceived capability. Availability of majors is one of the primary considerations shaping actual matriculation (Choy and Ottinger 1998; Hossler et al. 1999). Also, Brennan (2001) states that admission criteria as a proxy for quality is potentially more important than the program offering. 
Table 1: The frequencies and the percentages of the types of the information students gathered

\begin{tabular}{|l|c|c|}
\hline \multicolumn{1}{|c|}{ Type of information } & Frequency & \% \\
\hline Admission criteria & 51 & 100 \\
\hline Quality of degree and diploma offered & 25 & 49 \\
\hline Scholarship opportunities & 25 & 49 \\
\hline Maps of faculty grounds or pictures of faculty & 24 & 47 \\
\hline Atmosphere of students socializing and studying & 23 & 45 \\
\hline Sports activities and facilities available & 20 & 39 \\
\hline Academic studies and reputation & 18 & 35 \\
\hline Artistic, social programs and facilities available & 16 & 31 \\
\hline Curriculum and courses & 14 & 27 \\
\hline Students clubs & 14 & 27 \\
\hline
\end{tabular}

Surprisingly, Table 1 shows that less than $50 \%$ of the students gathered the other types of information, whereas, the literature suggests that information about social life and social activities of the institution, campus life, location financial aids, courses and quality or reputation of the program or university are key criteria in the decision to attend an institution of higher education (Ihlanfeldt 1980; Litten 1982; Straumanis 1987; John 1990; Bruwer 1996; Cullen and Edgett 1998; Choy and Ottinger 1998; Hossler et al. 1999; Kern 2000; Brennan 2001).

Table 2: Comparison of the types of sources of information student applied and percentage of the students who applied these by the number of information gathered

\begin{tabular}{|c|c|c|c|c|c|}
\hline \multirow[t]{2}{*}{ Types of source of information } & \multirow{2}{*}{$\begin{array}{c}\text { Usage } \\
(\%)\end{array}$} & \multirow{2}{*}{$\begin{array}{c}\text { Rank } \\
\text { of } \\
\text { usage }\end{array}$} & \multicolumn{2}{|c|}{$\begin{array}{c}\text { Percentage of student by the number } \\
\text { of collected information (\%) }\end{array}$} & \multirow{2}{*}{$\begin{array}{l}\text { Rank of } \\
\text { usefulness }\end{array}$} \\
\hline & & & - & + & \\
\hline Guidebook to place for higher education & 98 & 1 & 73 & 27 & 10 \\
\hline Family and relatives & 74 & 2 & 66 & 34 & 9 \\
\hline Teachers and counselors in secondary school & 36 & 3 & 64 & 36 & 8 \\
\hline Friends and neighbors & 27 & 4 & 48 & 52 & 6 \\
\hline Faculty students & 26 & 5 & 58 & 42 & 7 \\
\hline Brochures and handbook & 26 & 6 & 58 & 42 & 7 \\
\hline $\begin{array}{l}\text { The Internet (related webs and web pages of } \\
\text { the university) }\end{array}$ & 17 & 7 & 47 & 53 & 5 \\
\hline National or local newspaper and magazines & 14 & 8 & 21 & 79 & 3 \\
\hline Lecturers & 11 & 9 & 22 & 78 & 4 \\
\hline Faculty staff & 10 & 10 & 20 & 80 & 2 \\
\hline $\begin{array}{l}\text { Faculty visits which organized by secondary } \\
\text { school or personal visits }\end{array}$ & 8 & 11 & 11 & 89 & 1 \\
\hline
\end{tabular}


Table 2 indicates percentages of students who used the sources of information. Guidebook to place for higher education was the most used (98\%) information source. $74 \%$ of the students turned to their families and relatives for information. Moreover, in previous studies, it is stated that parents and relatives have an important affect on student's attending an institution of higher education (Hossler et al. 1990; Frisbee et al. 2000). Hossler and Gallagher (1987) stated that parents and peers influence the enrollment decision. Brennan (2001) stated that family and friends are perceived as having the greatest degree of source credibility and their advice is much more believable. But, in this study, it was found that only $27 \%$ of the students turned to their friends and neighbors. Formal sources of interpersonal information such as agents, experts, university staff and counselors are less easily accessed than informal sources such as friends, family, neighbors and relatives. However, formal sources may be more believable if the product is perceived to be highly technical (Moorthy et al. 1997). It is indicated in Table 2 that teachers and counselors in secondary school (36\%), lecturers (11\%) and faculty staff $(10 \%)$ had not been heavily consulted. However, teachers and counselors in secondary school have been more used a source of advice by the students than friends and neighbors.

Table 2 also indicates that sources of non-personal information (Brochures and handbooks, internet and National or local newspaper and magazines) had been used less. Whereas, the internet can provide all the information currently available in books, college catalogues, class bulletins, financial aid brochures, and so forth (Hossler 1999). Paulsen (1990) states that college publications are one of the six most preferred information sources for both parents and students. It is also reported in Table 2 that information from faculty students was sought by only $26 \%$ of the students. However, it was pointed out in past studies that alumni are an important means of recruitment and promotion (Devier 1982; Isbell and Lovedahl 1989; Hossler et al. 1990).

Campus visits are the most effective source of information in helping students about their choice decision (Craft 1980; Hossler et al. 1990; Wanat and Bowles 1992; Yost and Tucker 1995). But, this study indicates that campus visits were the least used source of information with 8 percent. Consequently, these findings indicate that easily available information sources were used more extensively than not easily available information sources.

Table 2 also shows percentages of the students according to the number of information that they have collected. In Table 2, whereas the negative mark means inadequate, the positive mark means adequate. These are defined as followed;

- $\quad$; shows the percentage of the students who collected five or less types of information within students using related source.

$+\quad$; shows the percentage of the students who collected six or more types of information within students using related source. 
To identify a relationship between types of source used and amount of information obtained, the Chi-Square analysis was carried out. It was found that there was a significant relationship $(\mathrm{X} 2=34,443, \mathrm{df}=10, \mathrm{p}<.001)$ between these two factors. This result is indicated as the rank of usefulness of the information sources in this table. Consequently, the results of this analysis indicate that the more used sources gave less information, while the less used sources gave more information.

Table 3: The frequency and the percentage of factors the students took into consideration

\begin{tabular}{|l|c|c|}
\hline \multicolumn{1}{|c|}{ Factors } & Frequency & \% \\
\hline To be adequate for my SSE score & 30 & 59 \\
\hline To led to a job when I graduate & 22 & 33 \\
\hline Fees and costs associate with study & 19 & 33 \\
\hline Proximity to home & 17 & 22 \\
\hline To be appropriate to my aptitudes & 11 & 20 \\
\hline Size of campus and faculty & 10 & 18 \\
\hline Job prestige & 9 & 6 \\
\hline Image and reputation of faculty & 5 & 4 \\
\hline Shelter facilities & 3 & 4 \\
\hline Scholarship facilities & 2 & 4 \\
\hline Prestige of chemistry & 2 & 2 \\
\hline Relevance of course to my chosen career & 2 & 2 \\
\hline Educational facilities such as library, classrooms and lab & 1 & 0 \\
\hline Prestige of lecturer & 1 & 0 \\
\hline Activities such as sports, arts and societies & 6 & \\
\hline Campus facilities such as faculty buildings, gardens and sports fields & & \\
\hline Other factors & & \\
\hline
\end{tabular}

As shown in Table 3, the SSE score is the most important factor that influenced students' choice, and the next two factors are related to the students' economic state. Proximity to home is the fourth factor students took into consideration during decision making. Table 3 shows that the other factors were taken into consideration by less than $25 \%$ of the students.

\section{Qualitative Data Analysis}

In the interviews, the following questions with their probes in parenthesis were asked: What kind of difficulties did meet during the search process for entry to higher education? (Give me an example). What was the role of information from sources close to you? (e.g. family, 
relatives, friends and neighbors etc). What was the role of information from sources which are near to your faculty in this process? (e.g. lecturers, staff and students etc). What was the role of your school in this process? (e.g. teachers, counselors and school organizations etc). Did you use non-personal information sources? (e.g. guidebook to place for higher education, brochures, handbooks, media, internet, and web pages etc). Did you make faculty and campus visits individually? What do you think about whether you find the expectations or you not find for your program? (Give an example). Why did you take SSE again?

Results are presented under three main headings, namely the search phase, the choice phase and the persistence phase, and these headings were showed with their codes in Figure 1. Predisposition phase was not needed in this analysis because interviewees intended to reenroll.

\section{SEARCH}

The overwhelming response of the interviewees indicates that they feel that they have used the information sources inadequately. This suggests that there is a lack of search motivation among the students. For example, one of the interviewees said that "I have not consulted enough....I mean I did not do much research" and "I have never talked to lecturers and staff.......I mean it was already defined what I have in mind" and "Although there is internet in my school, I have never used it......I made a superficial search."

With respect to the role of information sources in the search process, interviewees are in agreement about the low effectiveness of information sources. A typical response was, “....assistance from my counselor and other teachers was inadequate......and my school has never organized a campus visit" and "...there was only information about program quotas and extra points in the guidebook for higher education place..... m mean it was not indicated which universities had what kind of facilities."

\section{CHOICE}

In general, interviewees complained about being forced to decide according to the SSE score. For example, “.....SSE score was the only point that we took into consideration. So, I directly thought whether I can be placed or not into a program according to my SSE score......my choice changed completely when my SSE score was explained."

All the interviewees stated explicitly that one of the most significant factors in the choice phase was job opportunities. The fear of being jobless at the end of education affected their choice. A typical response was "to study in a higher education institution that has the possibility of finding a job was important for me". 
Figure 1. Results of interview data.

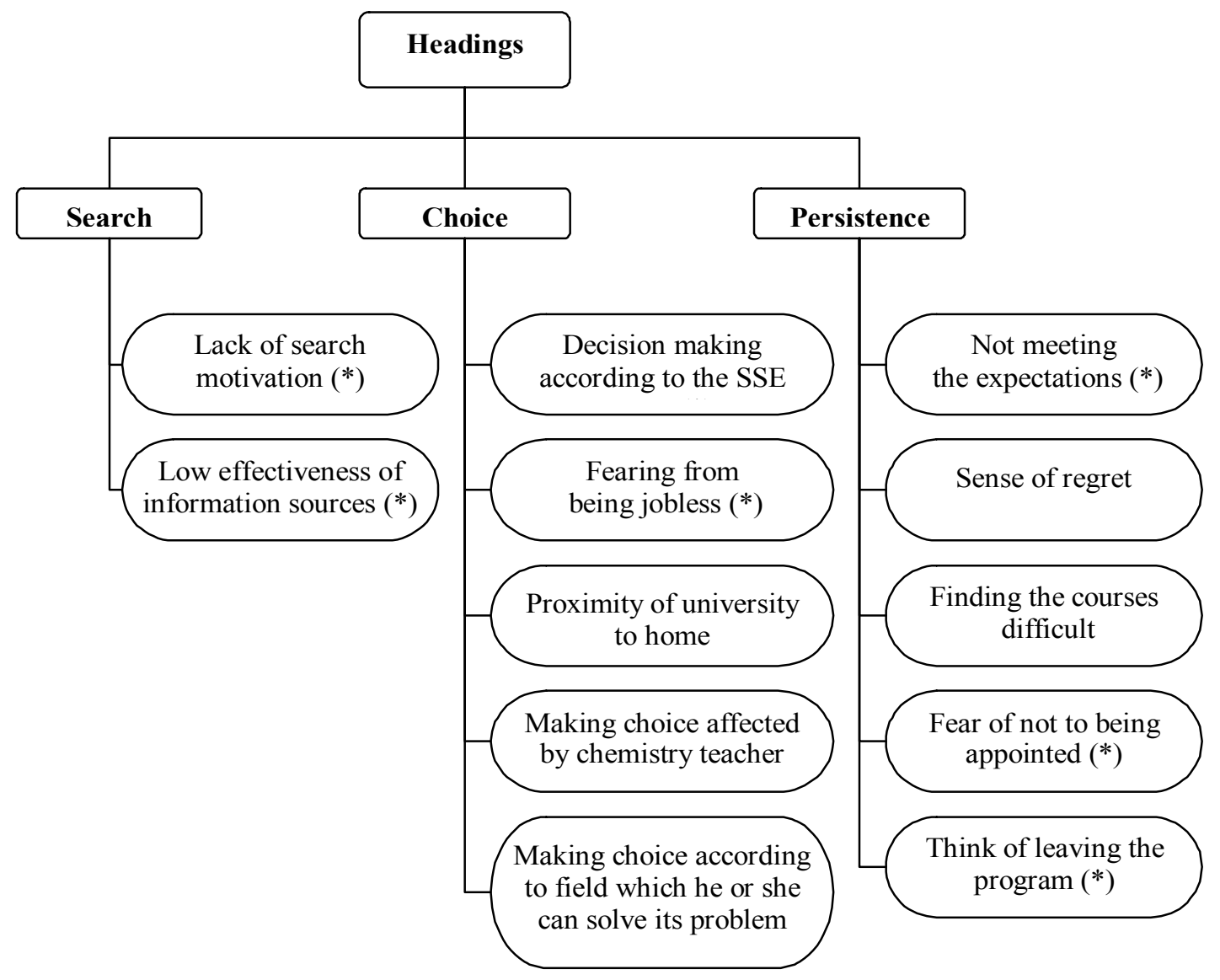

$\left(^{*}\right)$ indicates that all interviewees were agree.

As some interviewees stated they took into consideration the proximity of university to their home during choice phase, some interviewees stated that their choice was affected by their chemistry teacher. Few interviewees explained that they made choice according to types of question which he or she can solve in the SSE. For example, such a student will choose the Department of Chemistry Education instead of the Department of Biology Education so that he or she can more solve the questions of chemistry rates than those of biology.

\section{PERSISTENCE}

In response to the question, "were your expectations fulfilled?", it was noted that all interviewees did not fined their expectations fulfilled. For example, “....I expected several things from the Chemistry Teacher Training Program but the program did not meet my expectations.... I found it was very different after I began study in here.....I mean I'm disappointed when I came here." 
The overwhelming response to the question, "why did you take SSE again?", suggested that they were worried about whether they will be placed or not, and a typical response to this question was, “.....I want to be a good chemistry teacher but I don't know whether I will get such an opportunity or won't..."

Views of some interviewees indicate that they had a sense of regret, and also it is understood that few interviewees experienced difficulty in following the courses. The overall view is that all interviewees think about leaving the program. They think about changing the program, the university or both. For example, "I will try to attend a university which meets my actual ideals...... mean I will choose a program in which I will not regret studying it.”

\section{DISCUSSION AND CONCLUSIONS}

In this study, we aimed to investigate students' behaviors in relation to search and choice during university placement, and also to examine how students' choice processes affect their persistence. The extent of searching may be determined by the time spent, the amount of active search (campus visits), options considered and variety of sources of information used by the matriculates (Newman and Staelin 1972).

Both survey and interview data indicate that information search activities of the students were inadequate and they lacked search motivation during the search phase. Differently from previous studies this study shows that in general the students took into consideration the SSE scores as the most important factor which influenced their choice process. Therefore, they might have thought as "I want to attend any program for which my SSE score is adequate, that is, other factors are not very important for me" or "A program is good if its score is high." Another significant factor for most of the students is the economic status of the job which they will have in future. Therefore, they might have thought that "the kind of the program is not important for me, if it gives me a job when I graduate". Such thoughts impede their consideration about the institution of higher education. In addition, the results indicate that most of the information sources have low effectiveness. Quality of information sources may affect the students' search phase negatively. Cabrera and Nasa (2000) stated that the importance of securing accurate information about college extends well beyond the decision to enroll in college. The findings suggest that there were negative feelings in the students' search and choice phases. For solving this problem, a recruitment office should have been established for faculty and recruitment tools should have been activated. High schools should make their counseling activities more effectively, and finally, it is necessary that policymakers enterprise to expand the amount of financial aid. 
Table 4: A four phase model of college or university choice process

\begin{tabular}{|c|c|c|c|}
\hline \multirow[b]{2}{*}{ Model Dimensions } & \multicolumn{2}{|c|}{ Influential Factors } & \multirow[b]{2}{*}{ Student Outcomes } \\
\hline & $\begin{array}{l}\text { Individual } \\
\text { Factors }\end{array}$ & $\begin{array}{l}\text { Organizational } \\
\text { Factors }\end{array}$ & \\
\hline $\begin{array}{l}\text { Predisposition } \\
\text { (Phase one) }\end{array}$ & $\begin{array}{l}\text { Student } \\
\text { characteristics } \\
\text { Significant others } \\
\text { Educational activities }\end{array}$ & $\begin{array}{l}\text { School } \\
\text { characteristics }\end{array}$ & $\begin{array}{l}\text { Search for: } \\
\text { a. College options } \\
\text { b. Non-educational } \\
\text { options }\end{array}$ \\
\hline $\begin{array}{l}\text { Search } \\
\text { (Phase two) }\end{array}$ & $\begin{array}{l}\text { Student preliminary college } \\
\text { values } \\
\text { Student search activities }\end{array}$ & $\begin{array}{l}\text { College and university search } \\
\text { activities } \\
\text { (Search for students) }\end{array}$ & $\begin{array}{l}\text { a. Choice set } \\
\text { b. Non-educational } \\
\text { options }\end{array}$ \\
\hline $\begin{array}{l}\text { Choice } \\
\text { (Phase three) }\end{array}$ & Choice set & $\begin{array}{l}\text { College and university } \\
\text { courtship activities }\end{array}$ & Choice \\
\hline $\begin{array}{l}\text { Persistence } \\
\text { (Phase four) }\end{array}$ & $\begin{array}{l}\text { Quality of student's search } \\
\text { activities } \\
\text { The level of fulfillment of } \\
\text { student expectations } \\
\text { Student's college } \\
\text { or university experiences }\end{array}$ & $\begin{array}{l}\text { Quality of } \\
\text { university } \\
\text { activities }\end{array}$ & $\begin{array}{l}\text { a. Continue decision } \\
\text { b. Return to the } \\
\text { search phase } \\
\text { c. Leave decision } \\
\text { (non-educational } \\
\text { options) }\end{array}$ \\
\hline
\end{tabular}

In addition, the results of the study suggest another phase for the students in college choice process: the persistence phase (Table 4). Hossler and Gallagher (1987) proposed a three phase model of college choice. At each phase of this model, individual and organizational factors interact to produce outcomes which influence the student college choice process. Table 4 was modified from this model. Our study indicates that college choice process will restart for students who think to change their programs, university or both. Table 4 suggests a four phase model of college choice covering a persistence phase in which students may return to search phase or may continue life their actual study.

The results of this study also indicate that quality of students' search activities, level of fulfillment of their expectations and their college or university experiences affect their persistence. Also, qualities of university recruitment activities and school counseling activities have an influence on the students' persistence. Finally, students may leave or continue according to quality of the persistence phase. 


\section{IMPLICATION FOR SCIENCE EDUCATION}

It is clear that such a chemistry classroom students have difficulties in science learning. To prevent this problem, science learning environment of probable departments should be advertised well in high school counseling activities. Science classrooms, laboratories, library and other facilities are needed to be presented visually during the activities. Also science educators should design diagnostic studies for characteristics of a science teacher. That the counselor know the interests and abilities which are needed to be a science teacher is necessary for an effective counseling for the students in the choice of a science education department. 


\section{REFERENCES}

Astin, A.W. (1975). Preventing Students from Dropping Out, San Francisco: Jossey-Bass.

Bean, J.P. (1990).'Why students leave: insights from research', in Hossler, D. and Bean, J.P. and Associates (ed.), The Strategic Management of Enrollment. San Francisco: Jossey-Bass.

Belcher, G., Frisbee, R. and Standford, B. (2003). 'Differences between faculty and students' perception of recruitment techniques that influence students to attend four-year automotive programs', Journal of Career and Technical Education 19(2) 7-14.

Brennan, L. (2001). How Prospective Students Choose Universities: A Buyer Behavior Perspective. Doctoral dissertation, University of Melbourne, Australia.

Bruwer, J.D.W. (1996). 'Marketing a public higher educational institution through target market research on its freshman applicant and enrollee pools'. SAJHE/SATHO 10(2), 120-129.

Cabrera, A.F. and Nasa, S.M.L. (2000). Understanding the College-Choice Process. New Directions for Institutional Research. Jossey-Bass.

Cabrera, A.F., Nora, A. and Castaneda, M.B. (1992). 'The role of finances in the persistence process: A structural model', Research in Higher Education 33(5), 571-593.

Chapman, D.W. (1981). 'A model of student college choice', Journal of Higher Education 52(5), 490-505.

Chapman, R.G. (1984). Toward a theory of college choice: A model of college search and choice behavior, University of Alberta, Canada.

Choy, S.P. and Ottinger, C. (1998). Choosing a Postsecondary Education. Statistical Analysis Report. Washington, D.C.: Office of Educational Research and Improvement, National Center for Education Statistics, U.S. Department of Education.

Craft, C.O. (1980). Recruitment of industrial arts education majors: A professional obligation of all industrial arts educators. Man/Society/Technology, pp. 21-22.

Cullen, C.W. and Edgett, S.J. (1991). The cognitive and affective dimensions of involvement in service organization selection. Marketing through around the world. Dublin, European Marketing Academy 3, 633-650.

Devier, D.H. (1982). 'The recruitment of industrial arts teacher education students in Ohio with possible implications for the total profession', Journal of Industrial Teacher Education 19(3), 27-38.

Frisbee, R.L., Belcher, G. and Sanders, R.E. (2000). 'Recruitment techniques that influence students to attend fouryear automotive programs', Journal of Vocational Education Research 25(2), 104-125.

Hossler, D. (1999). Effective Admissions Recruitment. New Directions for Higher Education. Jossey- Bass.

Hossler, D., Bean, J.P. and Associates (1990). The Strategic Management of College Enrollments. San Francisco: Jossey-Bass.

Hossler, D., Braxton, J.M. and Coopersmith, G. (1989). 'Understanding student college choice', in Smart, J.C. (ed.), Higher Education: Handbook of Theory and Research. New York: Agathon Press. 
Hossler, D. and Gallagher, K.S. (1987). 'Studying student college choice: A three-phase model and the implications for policymakers', College and University 62(3), 207-221.

Hossler, D., Schmit, J. and Vesper, N. (1999). Going to College: How Social, Economic, and Educational Factors Influence the Decisions Students Make. Baltimore: Johns Hopkins University Press.

Hughes, J. (1994). 'Some likely consequences of the introduction of the university and college admission service', Higher Education Review 27(1), 7-22.

Ihlanfeldt, W. (1980). Achieving Optimal Enrollments and Tuition Revenues: A Guide to Modern Methods of Market Research, Student Recruitment. And Institutional Pricing. San Francisco: Jossey- Bass.

Isbell, C.H. and Lovedahl, G.G. (1989). 'A survey of recruitment techniques used in industrial arts/technology education programs', The Journal of Epsilon Pi Tau 15(1), 37-41.

Jackson, G. (1982). 'Public efficiency and private choicer in higher education', Educational Evaluation and Policy Analysis 4(2), 237-247.

John, E.P. (1990). 'Price response in enrollment decisions: An analysis of the high school and beyond sophomore cohort', Research in Higher Education 31(2), 161-176.

Kern, C.W.K. (2000). 'College choice influences: Urban high school students respond', Community College Journal of Research and Practice 24, 487-494.

Litten, L.H. (1982). 'Different strokes in the applicant pool: Some refinements in a model of students choice', Journal of Higher Education 4, 383-402.

Moorthy, S., Ratchford, B. and Talukdar, D. (1997). 'Consumer information search revisited: Theory and empirical analysis', Journal of Consumer Research 23(March), 263-277.

Nora, A. and Cabrera, A.F. (1992). 'Measuring program outcomes: What impacts are important to assess and what impacts are possible to measure?' Paper prepared for the Design Conference for the Evaluation of Talent Search. Washington. D.C.: Office of Policy and Planning. U.S. Department of Education.

Newman, J.W. and Staelin, R. (1972). 'Pre purchase information seeking for new cars and major household appliances', Journal of Marketing Research 9(3), 249-257.

Osoro, B.K., Amundson, N.E. and Borgen, W.A. (2000). 'Career decision-making of high school students in Kenya', International Journal for the Advancement of Counseling 22, 289-300.

Pascarella, E.T. and Terenzini, P.T. (1980). 'Predicting freshman persistence and voluntary dropout decisions from a theoretical model', Journal of Higher Education 51, 60-75.

Paulsen, M.B. (1990). College Choice: Understanding Student Enrollment Behavior. ASHE-ERIC Higher Education Report No. 6. Washington, D.C.: School of Education and Human Development. George Washington University.

Price, I., Matzdorf, F. and Smith, L. (2001). Where to study: Understanding the Importance of the Physical Environment to students in Choosing Their University. Research \& Application Forum Higher Education. Sheffield Hallam University. U.K. 
Somers, P., Cofer, J. and Putten, J.V. (1999). 'The influence of early aspirations and attitudes on postsecondary attendance'. American Educational Research Association Conference, Montreal, Canada.

SSPC (2004). Student Selection and Placement Center. Ankara.

Stage, F.K. and Hossler, D. (1989). 'Differences in family influences on college attendance plans for male and female ninth graders', Research in Higher Education 30(3), 301-315.

Straumanis, E. (1987). 'Positioning and trade-off analysis'. New Directions for Institutional Research 54 (Summer), 61-74.

Tatar, E. (2003). 'Investigation of the preference process of students who have preferred Department of Chemistry Education and relation between these processes and their attitude toward chemistry'. Master dissertation, University of Ataturk.

TIS (2004). Turkish Institution of Statistics. Ankara.

Tillery, D. (1973). Distribution and differentiation of youth: A study of transition from school to college. Cambridge, MA: Ballinger Publishing Company.

Tinto, V. (1987). Leaving College: Rethinking the Causes and Cures of Student Attrition. Chicago: University of Chicago Press.

Wanat, C.L. and Bowles, B.D. (1992). 'College choice and recruitment of academically talented high school student', The Journal of College Admission 136, 23-29.

Yost, M.J. and Tucker, S.L. (1995). 'Tangible evidence in marketing a service: The value of a campus visit in choosing a college', Journal of Marketing for Higher Education 6(1), 47-67.

\section{Erdal Tatar, Münir Oktay}

Atatürk Üniversitesi, Kazım Karabekir Eğitim Fakültesi

OFMAE Bölümü, Kimya Eğitimi Anabilim Dalı

25240 ERZURUM / TURKEY

E-mail: etatar@atauni.edu.tr

E-mail: yedigoze@atauni.edu.tr

Tel: +90.442 .2314029$

Fax: +90.442 .2360955$ 